\title{
Phosphorous dynamics in a temperate intertidal estuary
}

\author{
A.I. Lilleb $\varnothing^{\mathrm{a}, *}$, J.M. Neto ${ }^{\mathrm{a}}$, M.R. Flindt ${ }^{\mathrm{b}}$, J.C. Marques $^{\mathrm{a}}$, M.A. Pardal ${ }^{\mathrm{a}}$ \\ ${ }^{\mathrm{a}}$ IMAR - Institute of Marine Research, Department of Zoology, University of Coimbra, 3004-517 Coimbra, Portugal \\ ${ }^{\mathrm{b}}$ Institute of Biology, SDU - University of Odense, Campusvej 55, 5230 Odense M, Denmark
}

Received 1 December 2003; accepted 8 April 2004

\begin{abstract}
Conservation and management of aquatic systems require detailed information of the processes that affect their functioning and development. The objectives of the present work were to describe the phosphorus dynamics during a complete tidal cycle and to quantify the relative contribution of the most common estuarine areas (e.g. seagrass beds, salt marshes, mud- and sand-flats without vegetation) to phosphorus net internal loading in a temperate intertidal estuary.

Results show that phosphate efflux rates were higher during the first hours of tidal flood, and that phosphate concentrations were lowest at high tide. During tidal ebbing, ephemeral tide pools may cover a considerable percentage of the intertidal area. In these tide pools, water shallowness combined with enhanced temperatures stimulate the occurrence of high phosphate effluxes. The effluxes to the main water body during high tide contributed $57 \%$ of dissolved inorganic phosphorus and efflux during low tide contributed $43 \%$ to the net internal loading. Calculations of the phosphate net effluxes $(\mathrm{kg} \mathrm{P})$ indicate a strong contribution of the bare bottom mud-flats to the whole system internal phosphate loading, especially during the warmer periods.

As a consequence of eutrophication, perennial benthic macrophytes are commonly replaced by fast-growing epiphytic macroalgae. Calculations showed that for a hypothetical intertidal estuary in a temperate region, management programs considering an eventual re-colonization of mud-flats by seagrasses or salt marsh plants may reduce the P-efflux by $13-16 \mathrm{~kg} \mathrm{ha}^{-1}$. For example, in the small Mondego estuary, eutrophication has contributed to a reduction of the Zostera noltii meadows, leading to an increase in $190 \mathrm{~kg}$ of phosphorus net internal loading.

(c) 2004 Elsevier Ltd. All rights reserved.
\end{abstract}

Keywords: phosphate fluxes; tidal cycles; sediment-water; seagrass; salt marshes; estuaries

\section{Introduction}

Intertidal ecosystems are organized and controlled by a small set of key animal, plant, and abiotic processes that structure the substrate condition and the system functioning (Widdows and Brinsley, 2002). The biogeochemical processes, conditioned by $\mathrm{N}$ and $\mathrm{P}$ mediating bacteria, primary producers, bioturbation activity and through ecological engineering, may change the sediment adsorption/desorption capacity and the nutrient budgets of these systems (e.g. Kristensen, 1993; Staver et al., 1996; Gilbert et al., 1998; Mitchell and Baldwin, 1998; Flindt et al., 1999; Mortimer et al., 1999; Widdows and Brinsley, 2002). Biota living in the intertidal zone of mesotidal and macrotidal estuaries and coastal embayments are

\footnotetext{
* Corresponding author.

E-mail address: lillebo@ci.uc.pt (A.I. Lillebø).
}

adapted to a dynamic environment dominated by the tidal flooding and ebbing (Widdows and Brinsley, 2002). During tidal ebbing extensive areas of sand- and mudflats are covered by several low water pools (Flindt et al., 2002). During exposure of the tidal flats important biogeochemical processes take place in these ephemeral pools as a result of anabolic/catabolic balances, and of a combination of shallow water and enhanced temperature (Flindt et al., 2002; Lillebø et al., 2002a,b). The size of these pools may vary from some square centimetres to a few square metres.

Seagrasses and salt marshes share analogous functional role in the estuarine systems. Having high biomass values, these plant communities enhance the primary and secondary production of these habitats (e.g. Dolbeth et al., 2003). Due to the immediate changes in the physical environment (e.g. decreasing tidal currents, wave action and sediment resuspension, and 
enhancing sediment cohesiveness and settling of suspended matter) these primary producers are also biostabilisers (Flindt et al., 1999; Widdows and Brinsley, 2002). Additionally, submerged rooted macrophytes link the nutrients in sediments with the overlying water, with important implications for nutrient cycling (e.g. Short, 1987; Kamp-Nielsen and Flindt, 1993; Flindt et al., 1999). Plant roots have complex interactions with the surrounding sediment, covering a wide range of biogeochemical processes, namely changes in the rhizosphere chemistry, including the redox potential (Eh), organic matter content, metal availability and also the nutrient profiles (e.g. Caçador et al., 1996, 2000; Cartaxana and Lloyd, 1999; Flindt et al., 2002).

As a consequence of eutrophication processes, perennial benthic macrophytes are commonly replaced by fast-growing epiphytic macroalgae (e.g. Flindt et al., 1999; Den Hartog and Phillips, 2000; Cardoso et al., 2004), and these unbalanced situations may strengthen the phosphorus net internal loading.

Considering the Mondego estuary, a warm-temperate Atlantic coastal system, as a case study, the aim of this work was:

(a) To evaluate the efflux of phosphate during the tidal cycle,

(b) To quantify the seasonal contribution of common estuarine areas (salt marshes, seagrass meadows and bare bottom flats) to the efflux of inorganic phosphate, (c) To develop possible management scenarios for endangered temperate intertidal estuaries,

(d) To relate the calculated P-effluxes with the welldocumented eutrophication process ongoing in the Mondego estuary.

\section{Material and methods}

\subsection{Study site and sampling program}

The Mondego estuary is about $7 \mathrm{~km}$ long and is $2-3 \mathrm{~km}$ across at its widest part (Fig. 1). The estuary comprises a northern and a southern arm, separated by the Murraceira island. The northern arm is deeper ( $\pm 10 \mathrm{~m}$ during high tide, tidal range $0.5-3.5 \mathrm{~m}$ ) and constitutes the main navigation channel and the location of the Figueira da Foz harbour. The southern arm covers about $2.57 \mathrm{~km}^{2}$, and is almost silted up in the upper zones. The river outflow is mainly via the northern arm. Water circulation in the southern arm is mostly dependent on the tides and on the freshwater input from the Pranto River, a small tributary. This arm is shallower $(2-4 \mathrm{~m}$ during high tide, tidal range $1-3 \mathrm{~m}$ ), and is characterised by large areas of intertidal flats exposed during low tide. Scirpus maritimus marshes occupy the inner mud-flats, Spartina maritima marshes occur in the higher downstream areas, whereas Zostera noltii meadows occupy the lower downstream sand/

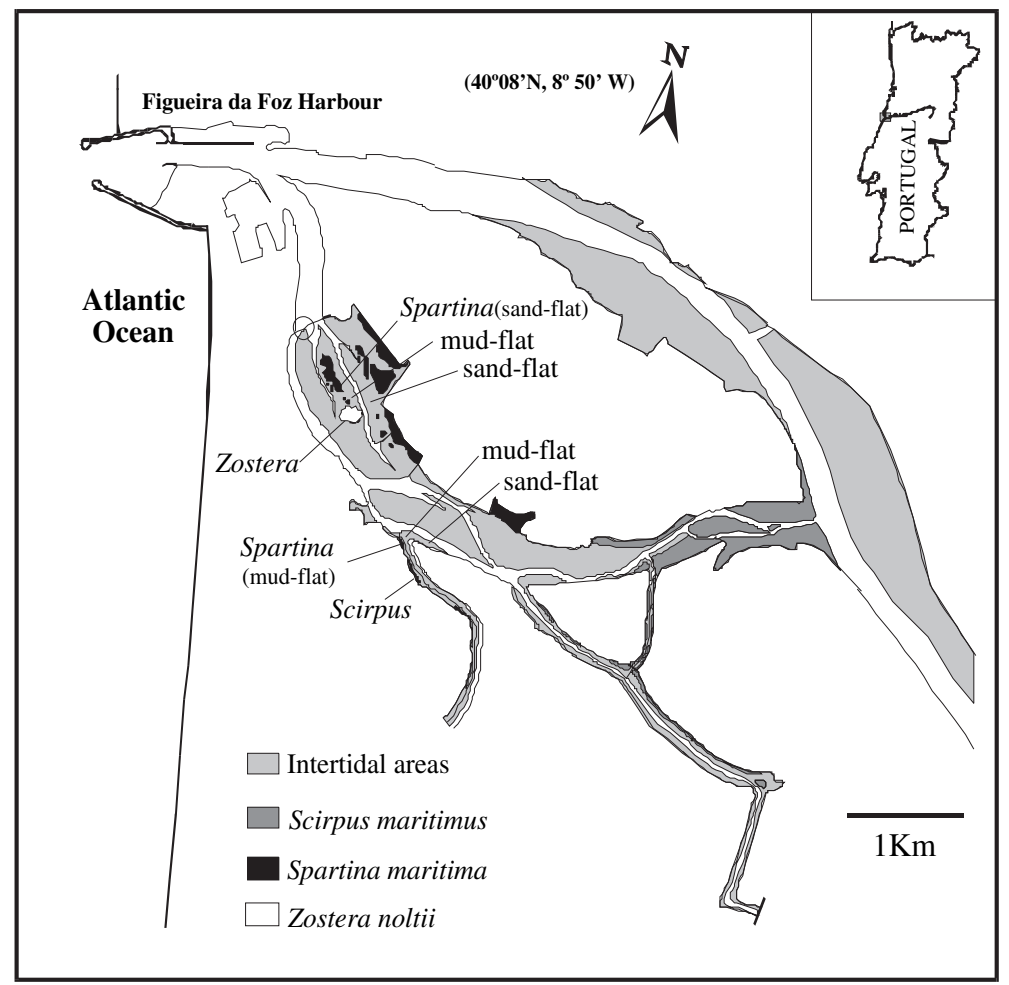

Fig. 1. The Mondego estuary, Portugal, with the location of the study sites. 
mud-flats. Sub-tidal areas (permanent channels) correspond to $32 \%$ of the total south arm area.

Freshwater flow from the Pranto River represents an important input of phosphorus into the southern arm (Flindt et al., 1997). The discharge from this tributary is controlled by a sluice regulated according to the water level of rice fields in the Mondego Valley. Phosphorous is transported adsorbed to particulate matter, especially during winter and early spring, usually following the seasonal variation of precipitation (Martins et al., 2001; Lillebø et al., 2002a). After sedimentation of particles, dissolved phosphate is released from the sediment particulate organic matter by $\mathrm{P}$-mineralization and $\mathrm{P}$ desorption, and thereby constitutes the efflux of phosphate to the water column (e.g. Falcão and Vale, 1998; Mitchell and Baldwin, 1998; Asmus et al., 2000; Lillebø et al., 2002a,b). In summer, inflow and outflow regime of the southern arm of the Mondego estuary depends essentially on tides. During low tide, the remaining water pools cover a considerable percentage of the total intertidal estuarine area, $60 \%$ in the mud-flats and $25 \%$ in the sand-flats.

Six study sites were established in the intertidal area of the southern arm (Fig. 1), considering exposure time, plant coverage and type of sediment: (a) a mud-flat covered by Zostera noltii $(0.3 \%)$; (b) a sand-flat covered by Spartina maritima (1\%); (c) a mud-flat covered by S. maritima (3\%); (d) a mud-flat covered by Scirpus maritimus (4\%); (e) two bare bottom mud-flats $(52 \%)$ and (f) two bare bottom sand-flat areas ( $8 \%$ ) (percentages refer to total area of south arm). Each area was characterised seasonally, in a day and night situation, for average water temperature, dissolved oxygen and salinity. Sediment samples (top $3 \mathrm{~cm}$ ) were analysed for percentage of organic matter content, estimated as loss on ignition (LOI) (Dwt-AFDW, $550{ }^{\circ} \mathrm{C}$ for $6 \mathrm{~h}$ ) (Table 1).

\subsection{Flux measurements at tidal flats}

Seasonally, flux measurements were performed at each of the study areas during 24-h cycles in order to cover a complete tidal cycle under a day and night situation. At each area and for each tidal cycle two methodologies were applied for P-flux measurements: (a) flux chambers during high tide and (b) the low tide pools during ebb. Additionally, a small sandy-muddy permanent channel without vegetation located at the outer boundary of the southern arm (black circle in Fig. 1) was followed during 12-h cycles, in order to track the phosphorus concentration in a complete tidal cycle.

All high tide campaigns were performed between 2000 and 2001. During tidal rise, Plexiglas tubes $(n=4$, $0.125 \mathrm{~m} \varnothing, 0.65 \mathrm{~m}$ length) were carefully filled with the main channel water, corresponding to the initial conditions $\left(t_{0}\right)$, and kept closed with a flexible impermeable membrane until the chamber was exposed again $\left(t_{n}\right)$. Phosphate fluxes were given by the difference between the amount of phosphate $\left(\mathrm{g} \mathrm{PO}_{4}-\mathrm{P} \mathrm{m}^{-2}\right)$ in time $\left(t_{n}\right)$ and the initial amount $\left(t_{0}\right)$, and then divided by the number of hours between the two samples $\left(\mathrm{g} \mathrm{PO}_{4}-\mathrm{P} \mathrm{m}^{-2} \mathrm{~h}^{-1}\right)$.

Water temperature, salinity and dissolved oxygen were measured at initial and final conditions. Flux chambers were also placed in the main channel (under day and night situations, in July 2001). During low tide, P-flux measurements were performed, between 1999 and 2000 , in tidal pools formed in sandy and muddy areas without vegetation, in Zostera noltii beds and in Spartina maritima marsh. Each pool was measured for surface area and depth. This study was not performed at the Scirpus maritimus salt marsh area due to the absence of large tide pools, although the area is covered by several minor pools. Water samples $(10 \mathrm{ml}$ each) were collected every hour, from pool formations until they were submerged again, and water temperature, salinity and dissolved oxygen were measured.

Phosphate fluxes were calculated taking into account the initial concentrations in the pool, which corresponded to the very first measurement just after the formation of the pool $\left(t_{0}\right)$. So, for each consecutive sample $\left(t_{1}, t_{2}, \ldots, t_{n}\right)$ the calculated rates were given by the difference between the phosphate amount $\left(\mathrm{mg} \mathrm{m}^{-2}\right)$ at time $\left(t_{n}\right)$ and the initial amount, and then divided by the number of hours between the two samples (data were previously standardised to avoid bias caused by differences in the pool size).

Seasonally and during full tidal cycles (12 h), water samples were collected hourly and water level measured in a small sandy-muddy permanent channel at the outer boundary of the southern arm. Water samples were immediately filtered (Whatman GF/F glass-fibre filter) and stored in ice. In the lab, samples were kept frozen at $-18{ }^{\circ} \mathrm{C}$ until analysis. Phosphate fluxes were calculated taking into account the initial water concentration $\left(t_{0}\right)$, and correspondent water level. So, for each consecutive sample $\left(t_{1}, t_{2}, \ldots, t_{n}\right)$ the calculated rates were given by the difference between the amount of phosphate $\left(\mathrm{g} \mathrm{PO}_{4}\right.$ $\left.\mathrm{P} \mathrm{m}^{-2}\right)$ in time $\left(t_{n}\right)$ and the initial amount, and then divided by the number of hours between the two samples $\left(\mathrm{g} \mathrm{PO}_{4}-\mathrm{P} \mathrm{m}^{-2} \mathrm{~h}^{-1}\right)$.

Analysis of dissolved reactive phosphate were carried out using a rapid flow autoanalyser (RFA 300 Alpkem) and performed according to the Alpkem methodologies (Alpkem, 1990).

\subsection{Calculations}

Calculations of the mean phosphate efflux rates per day, discriminating high and low tides $\left(\mathrm{mg} \mathrm{m}^{-2} \mathrm{~d}^{-1}\right)$, were performed considering the mean daily efflux rates (day and night) at each site, and the correspondent estuarine area $\left(\mathrm{m}^{2}\right)$. It was assumed that the mean efflux rates in May and July/August represented a mean value for spring and summer, respectively, and that the mean 
Table 1

The organic matter content of the sediment (in the top $3 \mathrm{~cm}$ ) at each study site, and average water temperature, dissolved oxygen and salinity, for day and night conditions during high and low tides, per season

\begin{tabular}{|c|c|c|c|c|c|c|c|}
\hline & \multirow{2}{*}{$\begin{array}{l}\text { Season } \\
\text { (day/night) }\end{array}$} & \multicolumn{3}{|l|}{ High tide } & \multicolumn{3}{|l|}{ Low tide } \\
\hline & & $\begin{array}{l}\text { Temperature } \\
\left({ }^{\circ} \mathrm{C}\right)\end{array}$ & Salinity & $\begin{array}{l}\text { Oxygen } \\
\left(\mathrm{ppm} \mathrm{O}_{2}\right)\end{array}$ & $\begin{array}{l}\text { Temperature } \\
\left({ }^{\circ} \mathrm{C}\right)\end{array}$ & Salinity & $\begin{array}{l}\text { Oxygen } \\
\left(\mathrm{ppm} \mathrm{O}_{2}\right)\end{array}$ \\
\hline \multirow{4}{*}{$\begin{array}{l}\text { Mud-flat } \\
\qquad(5-6 \% \text { O.M.) }\end{array}$} & Summer & $24.4-19.7$ & $26.9-22.8$ & $13.4-7.6$ & $22.6-15.2$ & $31.8-32.0$ & $5.9-3.7$ \\
\hline & Fall & $18.0-12.6$ & $31.2-26.4$ & $9.0-9.4$ & $15.5-13.6$ & $29.7-28.2$ & $6.8-5.9$ \\
\hline & Winter & $16.0-11.3$ & $2.1-2.9$ & $12.6-11.2$ & $10.8-6.0$ & $26.3-26.7$ & $5.9-4.0$ \\
\hline & Spring & $21.8-17.5$ & $2.9-2.7$ & $9.6-8.1$ & $17.9-15.4$ & $18.1-19.3$ & $7.6-6.4$ \\
\hline \multirow{4}{*}{$\begin{array}{l}\text { Sand-flat } \\
\qquad(0.95-1.13 \% \text { O.M. })\end{array}$} & Summer & $24.1-17.4$ & $30.3-23.0$ & $13.3-7.8$ & $21.8-15.4$ & $30.8-32.0$ & $8.8-5.9$ \\
\hline & Fall & $16.4-9.1$ & $30.8-25.7$ & $13.8-9.2$ & $15.2-14.1$ & $29.1-28.0$ & $8.8-5.8$ \\
\hline & Winter & $16.5-11.2$ & $4.2-8.9$ & $12.4-9.3$ & $10.3-6.0$ & $26.0-26.4$ & $5.5-4.3$ \\
\hline & Spring & $18.3-16.3$ & $2.25-1.9$ & $11.1-9.0$ & $17.0-14.9$ & $15.3-18$ & $8.8-6.9$ \\
\hline \multirow{4}{*}{$\begin{array}{l}\text { Spartina maritima } \\
\quad \text { sand-flat }(2.23 \% \text { O.M.) }\end{array}$} & Summer & & & & $23.6-15.5$ & $33.3-32.2$ & $10.6-3.4$ \\
\hline & Fall & & & & $16.2-15.2$ & $29.7-29.7$ & $7.2-2.6$ \\
\hline & Winter & & & & $10.4-7.4$ & $27.8-28.6$ & $6.5-3.9$ \\
\hline & Spring & & & & $17.6-15.6$ & $20.7-22.9$ & $8.3-6.3$ \\
\hline \multirow{4}{*}{$\begin{array}{l}\text { Spartina maritima } \\
\text { mud-flat ( } 8 \% \text { O.M.) }\end{array}$} & Summer & $27.1-19.6$ & $26.9-22.5$ & $13.7-5.6$ & $28.0-20.8$ & $25.9-27.5$ & $11.7-1.6$ \\
\hline & Fall & $18.4-10.2$ & $30.8-25.8$ & $11.27-8.4$ & $15.9-10.9$ & $2.1-3.6$ & $6.5-1.8$ \\
\hline & Winter & $17.2-11.0$ & $2.8-6.0$ & $* *-8.0$ & & & \\
\hline & Spring & $18.6-16.4$ & $2.1-2.0$ & $18.9-6.3$ & & & \\
\hline \multirow[t]{4}{*}{ Zostera noltii (2.25\% O.M.) } & Summer & $23.5-17.8$ & $30.0-23.0$ & $9.9-7.2$ & $23.4-15.7$ & $31.8-32.0$ & $12.7-4.2$ \\
\hline & Fall & $17.5-12.9$ & $31.0-26.0$ & $10.8-9.1$ & $15.8-14.1$ & $29.6-28.3$ & $8.4-1.9$ \\
\hline & Winter & $1.7-10.6$ & $1.6-2.9$ & $13.0-11.0$ & $10.8-5.9$ & $27.2-27.3$ & $9.6-4.1$ \\
\hline & Spring & $22.6-17.0$ & $2.9-2.6$ & $13.2-8.2$ & $17.3-15.6$ & $14.2-18.3$ & $9.1-7.3$ \\
\hline \multirow[t]{4}{*}{ Scirpus maritimus (8\% O.M.) } & Summer & $25.7-19.1$ & $16.7-17.2$ & $10.7-3.5$ & & & \\
\hline & Fall & $15.1-10.9$ & $25.9-24.4$ & $9.8-6.2$ & & & \\
\hline & Winter & $19.0-10.1$ & $0.8-0.8$ & $9.5-7.6$ & & & \\
\hline & Spring & $30.0-18.9$ & $1.4-0.9$ & $4.6-0.6$ & & & \\
\hline
\end{tabular}

efflux rates in November and January represented a mean value for fall and winter, respectively. Phosphate mass efflux $(\mathrm{kg} \mathrm{P})$ was also calculated taking into account each season's values.

To simulate the yearly variation in the phosphate fluxes from mud-flats, a simple dynamic temperature model was applied:

$\mathrm{PO}_{4}$ flux $_{\text {actual }}=\mathrm{PO}_{4}$ flux $t_{n} \times K^{(\text {tempactual }-n)}$

where the $\mathrm{PO}_{4}$ flux $_{t_{n}}$ is the measured phosphate flux at a certain temperature $\left({ }^{\circ} \mathrm{C}\right), K$ is temperature dependency constant, while $\mathrm{PO}_{4}$ flux actual is the simulated phosphate fluxes. The only forcing function was the temperature. In this application, the model simulates phosphate effluxes based on real weekly mean temperatures from 1999 to 2001.

\section{Results}

\subsection{Tidal cycles}

During a tidal cycle dissolved phosphate concentrations in the water column of the permanent channel located at the outer boundary of the southern arm increased during tide ebbing and decreased during tidal rise, especially in summer and spring (Fig. 2). During tidal rise phosphate efflux rates were higher during the first hours and then smoothly decreased. During ebb the efflux rates showed a sharp, sometimes a linear decrease (Fig. 3). Seasonally, P-efflux rates were higher in summer and spring and lower in fall and winter (Fig. 3).

Considering the entire south arm intertidal area, there was a seasonal variation of the environmental parameters during high and low tides, with higher temperature, oxygen concentration and salinity during summer and spring (Table 1). Moreover, in both situations there was a clear daily variation, with higher water temperature and dissolved oxygen during the day. This daily variation was more evident during low tide (tide pools), where the temperature range is much higher, and water may undergo oxygen depletion during the night, especially during the warmer periods (Table 1). Considering the southern intertidal estuarine area, these factors combined to promote a higher phosphorus efflux during low tide (Fig. 4).

\subsection{Contribution of different estuarine areas to P-mineralization and P-efflux}

Considering the mean daily efflux rates, there was a clear seasonal variation in the mud-flats, with higher 

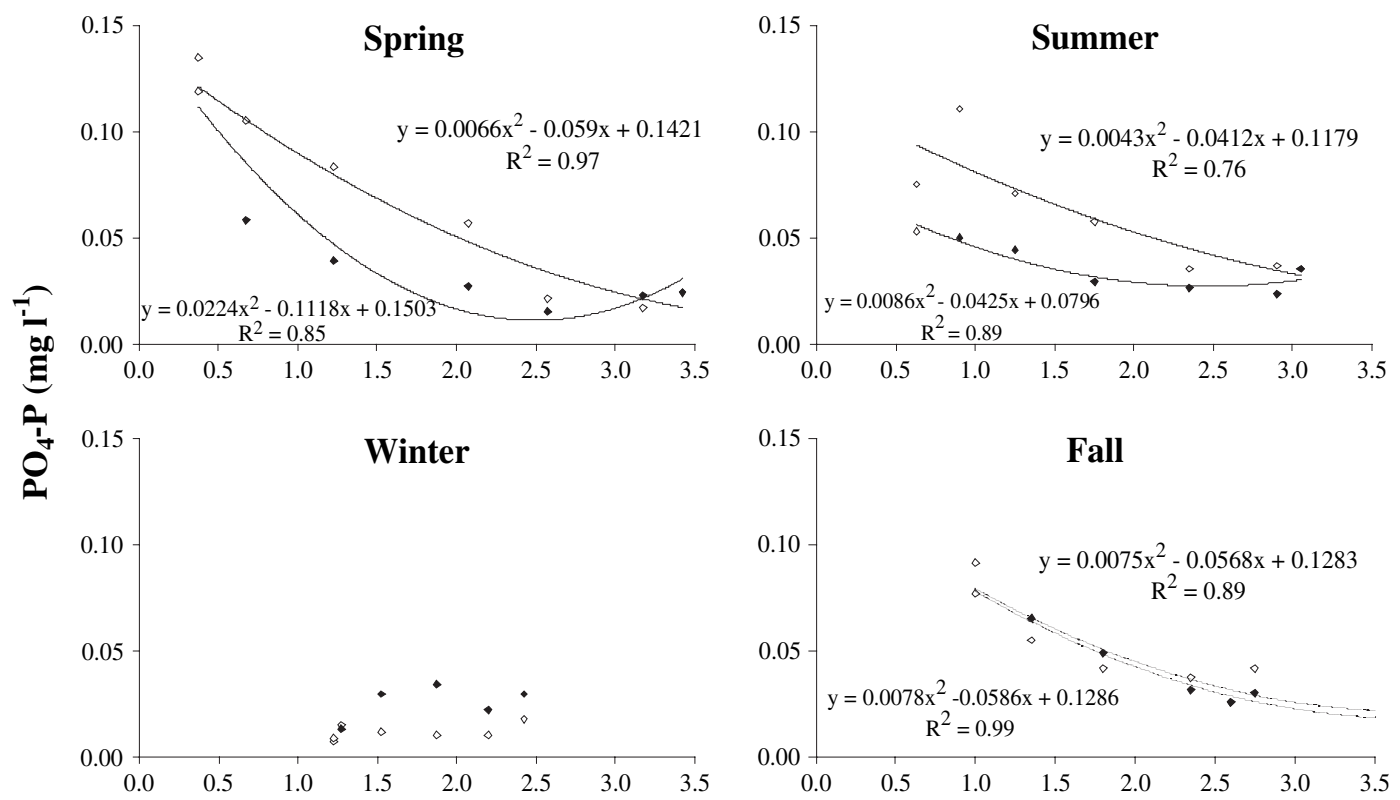

Tide height (m)

High tide

Low tide

Fig. 2. Variation of dissolved inorganic phosphate concentration in the main water body during a tidal cycle for each season.

P-effluxes during summer and spring, and lower P-effluxes during fall and winter, both in high and low tides (Fig. 5). This seasonal variation was not so well defined in the sand-flats, and it was assumed that there is no significant seasonal variation in the main channel.
Concerning the vegetated areas, none of them presented clear seasonal variation (Fig. 5). Calculations of the phosphate net effluxes (kg P), show the major contribution of the bare bottom mud-flats to the internal phosphate loading of the whole system and especially
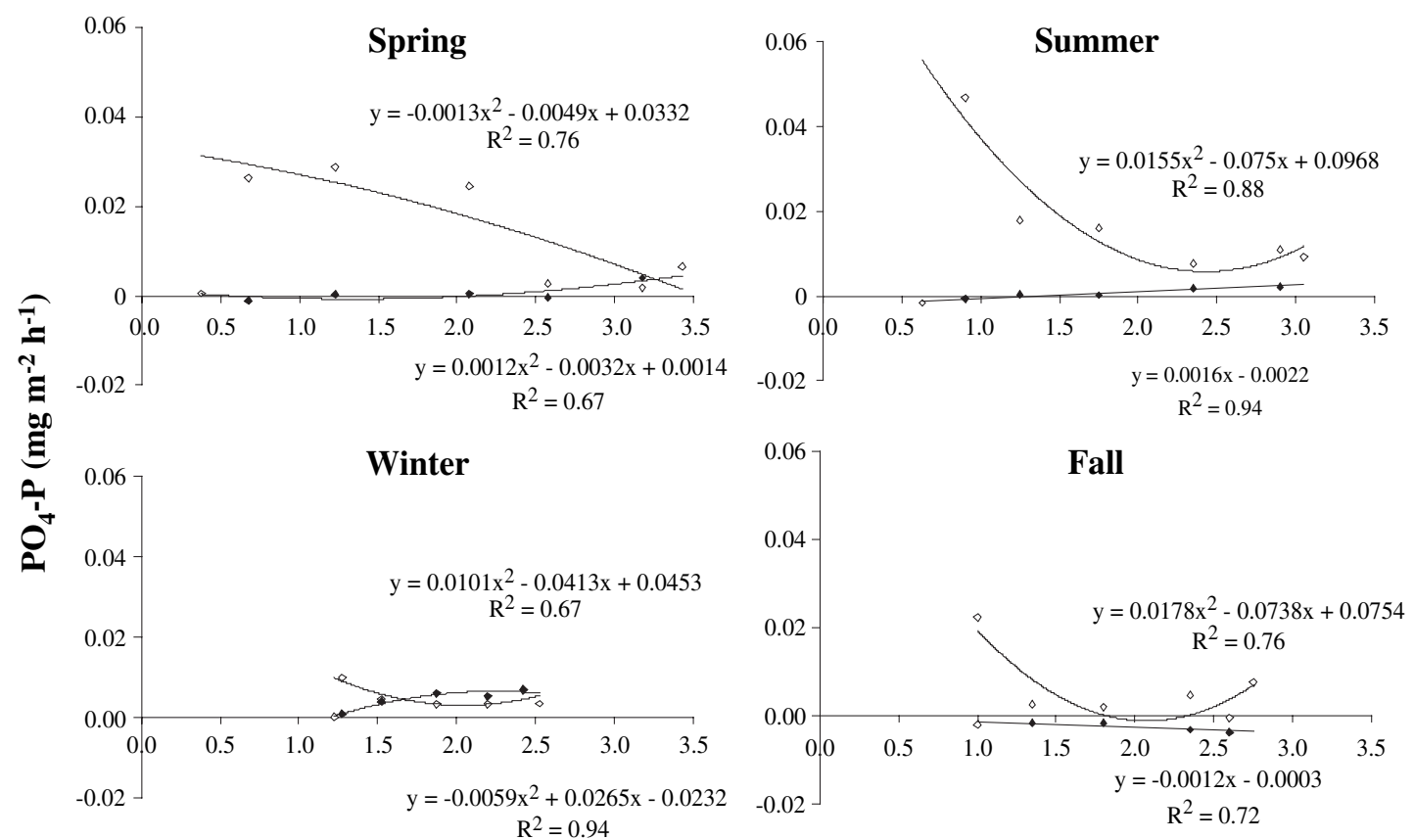

Tide height (m)

\section{High tide}

Low tide

Fig. 3. Variation of phosphate efflux rates to the main water body during a tidal cycle for each season. 


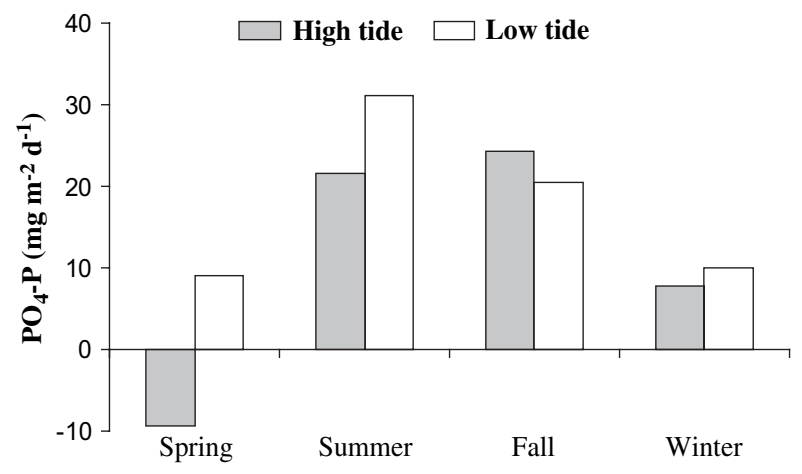

Fig. 4. Seasonal variation of daily P-efflux rates in the Mondego southern arm intertidal area, during high and low tides.

during the warmer periods (Fig. 6). The mud-flats represent $52 \%$ of the estuarine area and support $79 \%$ of the phosphate net fluxes. As P-effluxes in the mud-flats showed a clear seasonal variation, the internal loading of phosphate ( $43 \%$ contribution of low tide effluxes and $57 \%$ of high tide) was simulated based on a temperature-dependent model (Fig. 7). The model simulated phosphate effluxes based on real weekly mean temperatures from 1999 to 2001, and the fluxes show the same inter-annual pattern.

The seasonal/annual P-efflux from mud-flats and vegetated areas $\left(\mathrm{kg} \mathrm{PO}_{4}-\mathrm{Pha}^{-1}\right)$ provides evidence for plant specific seasonal variation (Table 2). Based on the annual calculated values, different scenarios for intertidal temperate estuaries may arise. If the replacement of mudflats by seagrasses or salt marsh plants was simulated it was observed that P-efflux from the sediment to the water column may decrease by $13 \mathrm{~kg}-16 \mathrm{~kg} \mathrm{PO}_{4}-\mathrm{P} \mathrm{ha}^{-1}$. This decrease may result from the uptake of phosphorus by plants for growth purposes and the increased adsorption capacity of the sediment in the plants rhizosphere.

Assuming the seasonal effluxes from the year 2000 as reference values, different scenarios for phosphorus annual net fluxes were simulated taking into account the area of the Mondego estuary covered by Zostera noltii in the last 16 years (Table 3 ). Results show that the reduction of the $Z$. noltii meadows as a consequence of eutrophication has enhanced the net internal loading of phosphorus by $190 \mathrm{~kg}$ (Table 3).

\section{Discussion}

During tidal rise, the higher phosphate efflux rates during the first hours may result from the contact of the incoming seawater, with lower phosphate concentration and lower temperature, with the rich warm superficial (low tide pools) or interstitial water. These differences may promote the phosphorus efflux to the incoming water column by diffusion (Falcão and Vale, 1998) and/ or convection processes. These differences will be attenuated as tide comes in, and phosphate efflux rates smoothly decrease. Even so, at high tide a slight increase in the phosphate concentration occurs probably due to the absence of currents just before the outgoing tide, allowing a water/sediment close contact and probably the activity of P-mediating bacteria. During tidal ebb the efflux rates showed a sharp, sometimes a linear decrease. Air exposed sediments have a substantially higher phosphate sorption capacity than submerged sediments (Mitchell and Baldwin, 1998). Nevertheless,
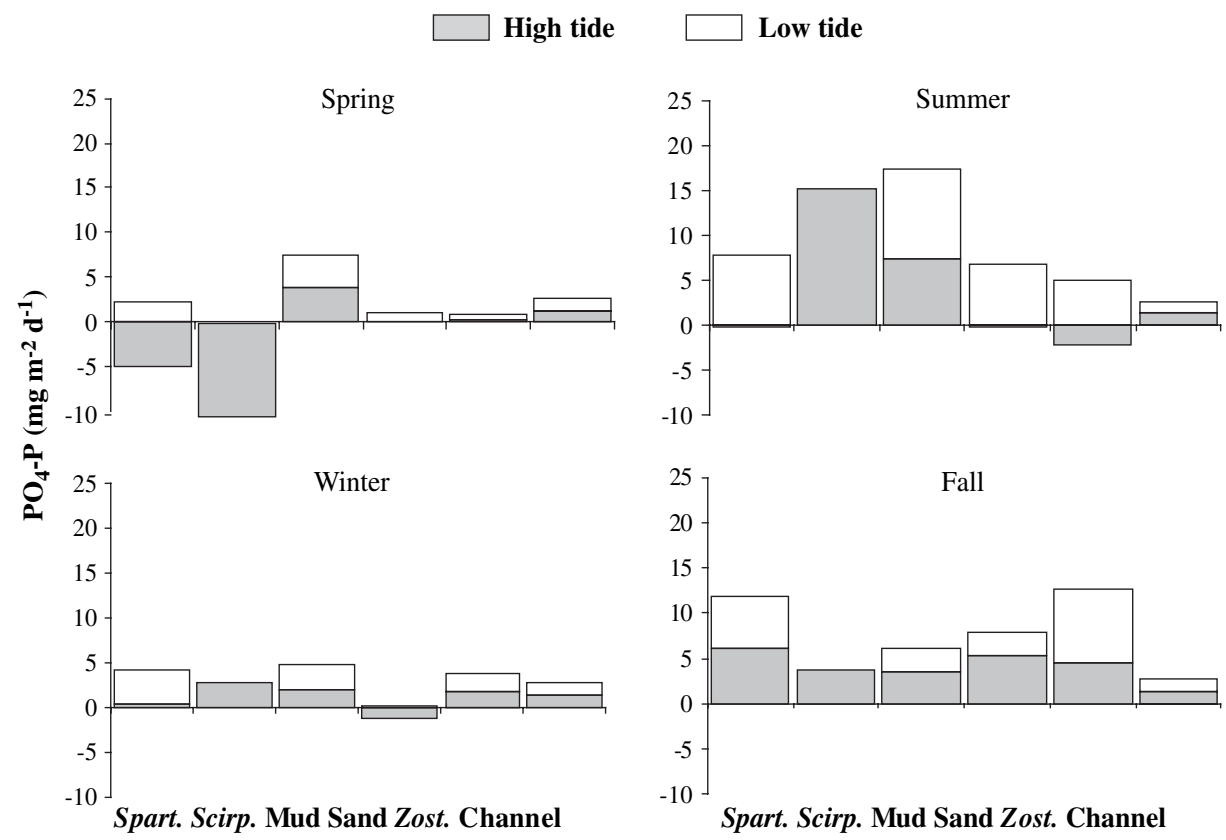

Fig. 5. Seasonal variation of daily phosphate efflux rates from each studied area, during high tide and in low water pools. 


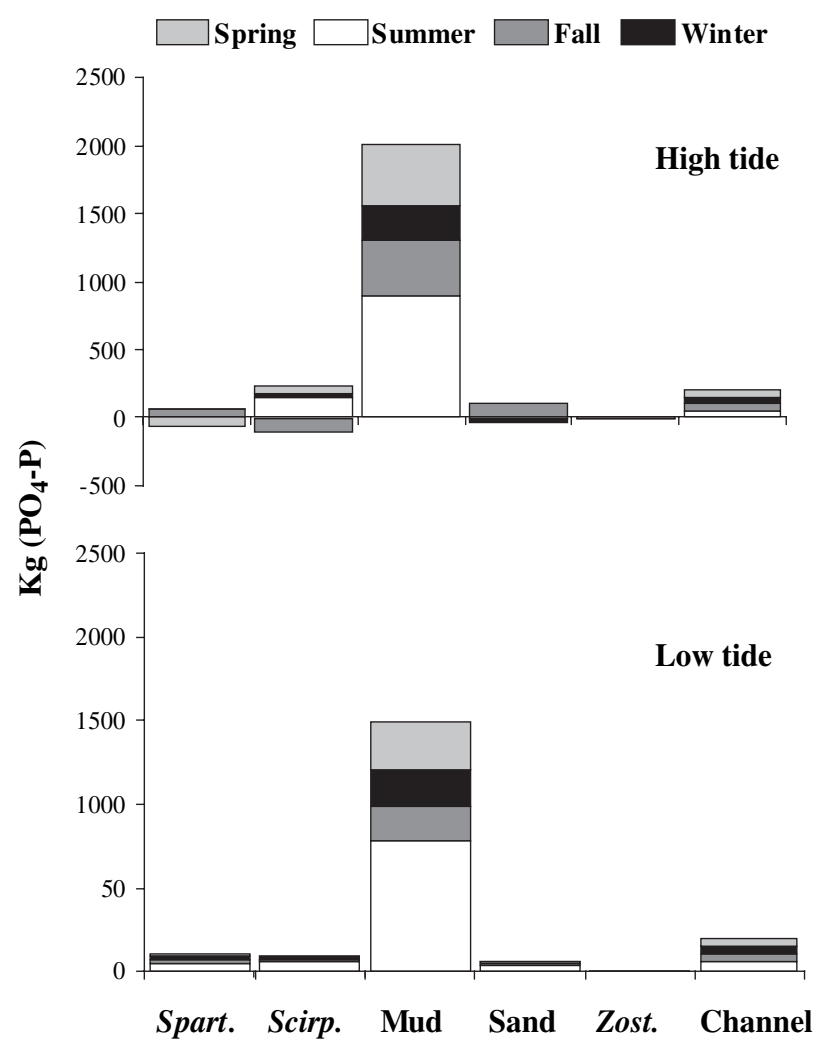

Fig. 6. Seasonal variation of net phosphate efflux rates from each studied area, during high tide and low tide (phosphate net flux in Scirpus maritimus during low tide in summer, fall and winter, were calculate based on mud-flat values).

at the same time, tide pools are formed all over the exposed areas. In these ephemeral pools, the quick increase of temperature in the shallow water and the oxygen depletion, stimulate the efflux of phosphate (Flindt et al., 2002; Lillebø et al., 2002a). The importance of the tide pools, varying from a few square centimetres to some square metres, to the efflux of phosphorus may be proportional to the area covered.

The results have shown that intertidal mud-flats constitute the major source $(79 \%)$ of phosphate in the southern arm of the Mondego estuary, and that $57 \%$ of

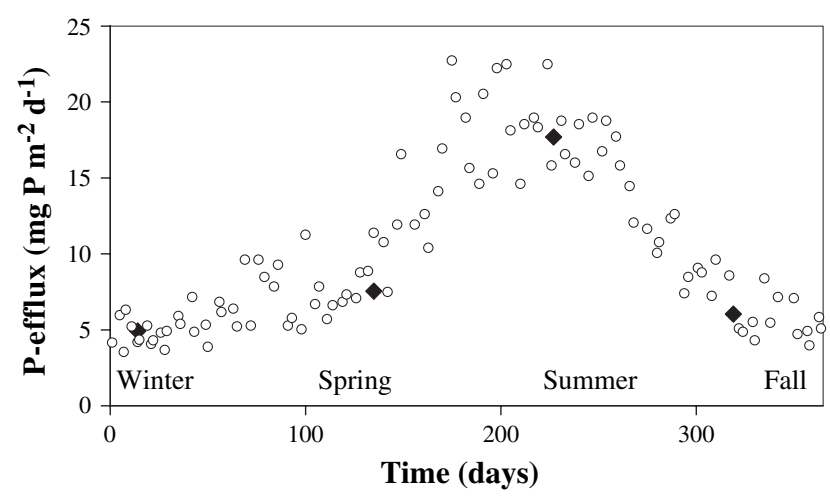

Fig. 7. Simulation of the yearly variation in phosphate fluxes, during high tide and low tide, in the mud-flats.
Table 2

Seasonal and annual P-effluxes $\left(\mathrm{kg} \mathrm{PO}_{4}-\mathrm{P} \mathrm{ha}^{-1}\right)$ from mud-flats and vegetated areas with evidence of plant specific seasonal variation and rhizosphere adsorption capacity

\begin{tabular}{lclcc}
\hline $\begin{array}{l}\text { Seasonal } \\
\left(\mathrm{kg} \mathrm{PO}_{4}-\mathrm{P} \mathrm{ha}_{1 / 4} \mathrm{y}^{-1}\right)\end{array}$ & $\begin{array}{l}\text { Spartina } \\
\text { maritima }\end{array}$ & $\begin{array}{l}\text { Scirpus } \\
\text { maritimus }\end{array}$ & $\begin{array}{l}\text { Zostera } \\
\text { noltii }\end{array}$ & Mud-flat \\
\hline Spring & -3.4 & -9.3 & 0.7 & 5.5 \\
Summer & 4.2 & 13.8 & 0.8 & 12.3 \\
Fall & 8.7 & 3.3 & 8.5 & 4.6 \\
Winter & 2.3 & 2.6 & 3.0 & 3.4 \\
Annual $\left(\mathrm{kg} \mathrm{PO}_{4}-\mathrm{P} \mathrm{ha} \mathrm{y}^{-1}\right)$ & $\mathbf{1 1 . 8}$ & $\mathbf{1 0 . 4}$ & $\mathbf{1 3 . 0}$ & $\mathbf{2 5 . 8}$ \\
\hline
\end{tabular}

the net phosphate flux occurred at high tide and $43 \%$ at low tide. The high content of organic matter, which is the main source of nutrients in the water column, and the elevated summer and spring temperatures, may cause these efflux rates. Mud-flats represent $52 \%$ of the total estuarine area, while sand-flats only represent $8 \%$. The mean organic matter content in sand-flats was substantially lower, less than $1 \%$. The low efflux rates in the permanent channels may result from the continuous water flow, and the fact that these sub-tidal areas are essentially constituted by sand.

Spartina maritima and Scirpus maritimus salt marsh areas and Zostera noltii meadows influenced phosphate release from the sediment: $S$. maritima salt marsh showed a relationship between seasonal phosphate effluxes and plant annual dynamics, especially during high tide. Although this species has a slow continuous growth (Adams and Bate, 1995) the flowering period is from May until July, which naturally carries extra nutrient demand. During spring even though the mean organic content is higher than in the mud-flats, S. maritima rhizosphere promotes a higher adsorption capacity of the sediment (Flindt et al., 2002). During this period, there was a low P-efflux during low tide and phosphate uptake during high tide. Additionally, epiphytes can be quite abundant at this time of the year. In summer, the lesser abundance of epiphytes and the higher temperatures in the low water pools may enhance phosphate effluxes. During low tide the balance between efflux and uptake was close to zero. In the fall, there was P-efflux during the tidal cycle, which was probably related to lesser plant activity, absence of epiphytes and a favourable temperature for P-efflux.

Table 3

Different scenarios for phosphorus $\left(\mathrm{PO}_{4}-\mathrm{P}\right)$ annual net fluxes (in the last 16 years), considering the estuarine area covered with $Z$. noltii and assuming the seasonal effluxes from the year 2000 as reference values

\begin{tabular}{lcll}
\hline Year & $\begin{array}{l}\text { Zostera noltii } \\
\text { area }\left(\mathrm{m}^{2}\right)\end{array}$ & $\begin{array}{l}\text { \% Efflux } \\
\text { mud-flats }\end{array}$ & $\begin{array}{l}\text { Annual net } \\
\text { efflux (ton) }\end{array}$ \\
\hline 1986 & 150000 & 73.8 & 4.14 \\
1996 & 200 & 79.4 & 4.33 \\
2000 & 8850 & 79.1 & 4.32 \\
2002 & 22000 & 78.7 & 4.30 \\
\hline
\end{tabular}


Finally, during winter the lower temperatures may inhibit this process. Scirpus maritimus marshes showed a close relationship between plant annual dynamics and the seasonal variation of phosphate effluxes during high tide. In the Mondego estuary this species has a particularly above ground life cycle with a growing season from January to April/May (Lillebø et al., 2003), explaining the high phosphate uptake during spring. Moreover, recent studies also show that during spring this species rhizosphere has a higher adsorption capacity than $S$. maritima. On the other hand, during summer, when plants die-back to the buried rhizomes, the efflux from the sediment maybe enhanced due to the high temperatures and the high organic matter contents of the sediment.

Zostera noltii meadow phosphate efflux rates clearly reflect the seasonal growth of this species and its ability to take up nutrients from the sediment via the rhizomes and from the water column through the leaves (Short, 1987). In the Mondego estuary, Z. noltii new leaves appeared in late February/March and the eelgrass meadows developed over the intertidal mud-flats in spring/ summer. Leaf cover began to decline during the late summer and autumn, which was expressed by the higher phosphate effluxes in fall during high and low tides.

Nutrient flux dynamics are strongly dependent on seasonal variation of temperature, and higher phosphate effluxes in temperate regions are found at higher temperatures (e.g. Asmus et al., 2000). In the Mondego estuary, mud-flats supply up to $79 \%$ of the total dissolved inorganic phosphorus that potentially can be exported into coastal waters. However, systems with larger plant covered areas, salt marshes or seagrass meadows, may experience different results, depending on species composition and on the relative percentage of each area. The calculated values for seasonal/annual P-effluxes show that an eventual colonization of bare bottom mud-flats by one of the three most common species in warm temperate estuaries (Zostera noltii, Spartina maritima and Scirpus maritimus) may reduce the phosphate internal loading by $13 \mathrm{~kg}-16 \mathrm{~kg}$ ha $\mathrm{y}^{-1}$. In the Mondego estuary, the $Z$. noltii meadow's reduction (Marques et al., 1997, 2003; Pardal et al., 2000; Martins et al., 2001; Cardoso et al., 2002; Dolbeth et al., 2003) has lead to a feed-back process with the increase of phosphorus effluxes of $190 \mathrm{~kg}$. This information may be of particular importance to programs for reversing habitat degradation in nutrient enriched aquatic systems.

\section{Acknowledgements}

This study was carried out in the scope of the POCTI-Formar e Qualificar-Medida 1.1 program
(Portuguese FCT) through a Post-Doc grant (SFRH/ $\mathrm{BPD} / 5650 / 2001$ ) (A.I. Lillebø) and a PhD grant (Praxis XXI/BD/18422/98) (J.M. Neto). Furthermore, it was supported by the research project DYNAMOD (POCTI/M6S137431/2001) also funded by the Portuguese FCT. The authors would like to thank the Freshwater Biological Laboratory, University of Copenhagen, Denmark, for the logistic support to conduct this study.

\section{References}

Adams, J.B., Bate, G.C., 1995. Ecological implications of tolerance of salinity and inundation by Spartina maritima. Aquatic Botany 52, 183-191.

Alpkem, 1990. Rapid Flow Analyser-Methodology A303-S202, A303-S170, A303-S020. ALPKEM Corporation, Clackamas, Oregon, USA.

Asmus, R.M., Sprung, M., Asmus, H., 2000. Nutrient fluxes in intertidal communities of a south European lagoon (Ria Formosa)-similarities and differences with a northern Wadden sea bay (Syl-Rømø bay). Hydrobiologia 436, 217-235.

Caçador, I., Vale, C., Catarino, F., 1996. Accumulation of $\mathrm{Zn}, \mathrm{Pb}, \mathrm{Cr}$ and $\mathrm{Ni}$ in sediments between roots of the Tagus estuary salt marshes, Portugal. Estuarine, Coastal and Shelf Science 42, 393-403.

Caçador, I., Vale, C., Catarino, F., 2000. Seasonal variation of Zn, Pb, $\mathrm{Cu}$ and $\mathrm{Cd}$ concentrations in the root-sediment system of Spatina maritima and Halimione portugaloides from Tagus estuary salt marshes. Marine Environment Research 49, 279-290.

Cardoso, P., Pardal, M.A., Lillebø, A.I., Ferreira, S.M., Marques, J.C., 2002. The effect of different primary producers on Hydrobia ulvae population dynamics: a case study in a temperate intertidal estuary. Journal of Experimental Marine Biology and Ecology 277, 173-195.

Cardoso, P., Pardal, M.A., Lillebø, A.I., Ferreira, S.M., Raffaelli, D., Marques, J.C., 2004. Dynamic changes in seagrass assemblages under eutrophication and implications for recovery. Journal of Experimental Marine Biology and Ecology 302, 233-248.

Cartaxana, P., Lloyd, D., 1999. $\mathrm{N}_{2}, \mathrm{~N}_{2} \mathrm{O}$ and $\mathrm{O}_{2}$ profiles in a Tagus estuary salt marsh. Estuarine, Coastal Shelf Science 48, 751-756.

Den Hartog, C., Phillips, R.C., 2000. Seagrasses and benthic fauna of sediment shores. In: Reise, K. (Ed.), Ecological Comparisons of Sedimentary Shores. Springer, Berlin, pp. 195-212.

Dolbeth, M., Pardal, M.A., Lillebø, A.I., Azeiteiro, U., Marques, J.C., 2003. Short term and long term effects of eutrophication on the secondary production of an intertidal macrobenthic community. Marine Biology 143, 1229-1238.

Falcão, M., Vale, C., 1998. Sediment-water exchanges of ammonium and phosphate in intertidal and subtidal areas of a mesotidal coastal lagoon (Ria Formosa). Hydrobiologia 373/374, 193-201.

Flindt, M.R., Kamp-Nielsen, L., Marques, J.C., Pardal, M.A., Bocci, M., Bendoricho, G., Nielsen, S.N., Jørgensen, S.E., 1997. Description of the three shallow estuaries: Mondego River (Portugal), Roskilde Fjord (Denmark) and the Lagoon of Venice (Italy). Ecological Modelling 102, 17-31.

Flindt, M.R., Pardal, M.A., Lillebø, A.I., Martins, I., Marques, J.C., 1999. Nutrient cycling and plant dynamic in estuaries: a brief review. Acta Oecologica 20, 237-248.

Flindt, M.R., Pardal, M.A., Lillebø, A.I., Martins, I., Oliveira, J.M., 2002. Nutrient dynamics in the intertidal pools of the Mondego estuary. I-Nutrients sources, sediment profiles, mineralisation and adsorption dynamics. In: Pardal, M.A., Marques, J.C., Graça, M.A. (Eds.), Aquatic Ecology of the Mondego River Basin. Global Importance of Local Experience. Imprensa da Universidade de Coimbra, Coimbra, pp. 243-256. 
Gilbert, F., Stora, G., Bonin, P., 1998. Influence of bioturbation on denitrification activity in Mediterranean coastal sediments: an in situ experimental approach. Marine Ecology Progress Series 163, 99-107.

Kamp-Nielsen, L., Flindt, M.R., 1993. On-line recording of porewater profiles from in situ dialysis. Verhandlungen Internationale Vereinigung für theoretische und angewandte Limnologie 25, $151-156$.

Kristensen, E., 1993. Seasonal variation in benthic community metabolism and nitrogen dynamics in a shallow, organic-poor Danish laggon. Estuarine, Coastal and Shelf Science 36, 565-586.

Lillebø, A.I., Pardal, M.A., Flindt, M.R., Neto, J.M., Macedo, F., Martins, I., Marques, J.C., 2002a. Nutrient dynamics in the intertidal pools of the Mondego estuary. IV-Possible contribution to dissolved inorganic phosphorus loading. In: Pardal, M.A., Marques, J.C., Graça, M.A. (Eds.), Aquatic Ecology of the Mondego River Basin. Global Importance of Local Experience. Imprensa da Universidade de Coimbra, Coimbra, pp. 287-300.

Lillebø, A.I., Flindt, M.R., Pardal, M.A., Martins, I., Neto, J.M., Marques, J.C., 2002b. Nutrient dynamics in the intertidal pools of the Mondego estuary. II-Seasonal efflux of $\mathrm{PO}_{4}-\mathrm{P}$ and $\mathrm{NH}_{4}-\mathrm{N}$ in bare bottom and vegetated pools. In: Pardal, M.A., Marques, J.C., Graça, M.A. (Eds.), Aquatic Ecology of the Mondego River Basin. Global Importance of Local Experience. Imprensa da Universidade de Coimbra, Coimbra, pp. 257-272.

Lillebø, A.I., Pardal, M.A., Neto, J.M., Marques, J.C., 2003. Salinity as the major factor affecting Scirpus maritimus annual dynamics. Evidence from field data and greenhouse experiment. Aquatic Botany 77, 11-120.

Marques, J.C., Pardal, M.A., Nielsen, S.N., Jørgensen, S.E., 1997. Analysis of the properties of exergy and biodiversity along an estuarine gradient of eutrophication. Ecological Modelling 62, 155-167.

Marques, J.C., Nielsen, S.N., Pardal, M.A., Jørgensen, S.E., 2003. Impact of eutrophication and river management within a framework of ecosystem theories. Ecological Modelling 166, 147-168.

Martins, I., Pardal, M.A., Lillebø, A.I., Flindt, M.R., Marques, J.C., 2001. Hydrodynamics as a major factor controlling the occurrence of green macroalgae blooms in an eutrophic estuary: a case study. Estuarine, Coastal and Shelf Science 52, 165-177.

Mitchell, A., Baldwin, D.S., 1998. Effects of desiccation/oxidation on the potential for bacterial mediated $\mathrm{P}$ release from sediments. Limnology and Oceanography 43, 481-487.

Mortimer, R.J.G., Davey, J.T., Krom, M.D., Watson, P.G., Frickers, P.E., Clifton, R.J., 1999. The effect of macrofauna on porewater profiles and nutrient fluxes in the intertidal zone of the Humber estuary. Estuarine, Coastal and Shelf Science 48, 683-699.

Pardal, M.A., Marques, J.C., Metelo, I., Lillebø, A.I., Flindt, M.R., 2000. Impact of eutrophication on the life cycle, population dynamics and production of Ampithoe valida (Amphipoda) along an estuarine spatial gradient (Mondego estuary, Portugal). Marine Ecology Progress Series 196, 207-219.

Short, F.T., 1987. The effects of sediment nutrients on eelgrasses: literature review and mesocosm experiment. Aquatic Botany 27, $41-57$.

Staver, L.W., Staver, K.W., Stevenson, J.C., 1996. Nutrients inputs to the Choptank River estuary: implications for watershed management. Estuaries 19, 342-358.

Widdows, J., Brinsley, M., 2002. Impact of biotic and abiotic processes on sediment dynamics and the consequences to the structure and functioning of the intertidal zone. Journal of Sea Research 48, 143-156. 